\title{
Killing Fields: Environment, Agency, and the Fascist Conquest of Colonial Libya
}

\section{Campos de Morte: Meio Ambiente, Agência, e a Conquista Fascista da Líbia Colonial}

\author{
Roberta Pergher, \\ Indiana University, Bloomington, USA
}

\begin{abstract}
The article seeks to reflect on the question of "nature's agency" in histories of violence. It thus revisits the choices and outcomes of Fascist policy in Libya by foregrounding the colony's ecology. The determination to win a war on inhospitable terrain led to the regime's decision to set up concentration camps for Bedouin tribes and their herds in the desert-like and semiarid areas of Cyrenaica, which in turn had a murderous effect on humans and animals. From there, the article moves on to the second phase of Italian conquest, when the defeat of the anticolonial resistance turned into a "conquest of nature", with the agricultural reclamation of the highlands of Cyrenaica for Italian settlers. These agricultural centers and their people, which might at first sight seem bucolic and benign, were just as injurious to the Bedouin ecology predating the Italian occupation as were the concentration camps. The conclusion ponders the moral imperatives in writing histories of Fascist violence and the openings for environmental history.
\end{abstract}

Keywords-Italy; Libya; Fascism; Colonialism; Genocide.

Resumo-O artigo procura refletir sobre a questão da "agência da natureza" nas histórias de violência. Assim, revisita as escolhas e resultados da políticas fascista na Líbia, colocando em primeiro plano a ecologia da colónia. A determinação de vencer uma guerra num terreno inóspito, levou à decisão do regime de criar campos de concentração para tribos beduínas e seus rebanhos nas áreas desérticas e semiáridas da Cirenaica, que por sua vez tiveram um efeito assassino em humanos e animais. A partir daí, o artigo segue para a segunda fase da conquista italiana, quando a derrota da resistência anti-colonial se transformou numa "conquista da natureza", com a recuperação agrícola das terras altas da Cirenaica para os colonos italianos. Esses centros agrícolas e o seu povo, que à primeira vista poderiam parecer bucólicos e benignos, eram tão prejudiciais à ecologia beduína anterior à ocupação italiana quanto os campos de concentração. A conclusão pondera sobre os imperativos morais em escrever histórias de violência fascista e as aberturas para a história ambiental.

Palavras-Chave-Itália; Líbia; Fascismo; Colonialismo; Genocídio.

Submitted-21-07-2021. Accepted-11-11-2021.

- Roberta Pergher, Associate Professor at the Department of History, Indiana University, Bloomington.

E-mail: rpergher@indiana.edu 


\section{Introduction}

T $\mathrm{N}$ the early 1930s, the southern rim of the 1 Mediterranean was the site of genocide. ${ }^{1}$ The tragedy unfolded in one of Italy's colonies, along the desertic western shore of the Gulf of Sidra and the semi-arid coastal areas of northwestern Cyrenaica. By late fall 1930, Benito Mussolini's regime had forced two thirds of the civilian population of Cyrenaica, around 100,000 people - men, women, children, the elderly, most of whom lived nomadic or semi-nomadic lives - into 16 separate camps. Some of the largest camps were located on barren land with no permanent settlements nearby; many prisoners walked over $1,000 \mathrm{~km}$ to get to their designated camp. Upon their release in 1932 and 1933, according to official Italian sources at least 40,000 people had lost their lives, but credible estimates put the number between 50,000 and $70,000 .^{2}$ Moreover, nearly 90 percent of the herds perished.

The Fascist regime, and indeed its liberal predecessors, had been almost permanently at war with the anticolonial resistance in the colonies of Tripolitania and Cyrenaica since Italy's 1911 occupation of the former Ottoman territories (Del Boca 1986 and 1988). The Fascists attributed the failure to quell the fighting in Cyrenaica to support for the guerilla war allegedly coming from the civilian population in the form of fighters, food, and tithes. To sever the link between combatants and civilian backers, the regime forced civilians into camps. Implemented under harsh environmental conditions, this policy decimated the nomadic and semi-nomadic tribes of Cyrenaica, and ended the resistance.

The environment - the climate, landscape, vegetation, and animals - having for years appeared to aid the local tribes in their fight against the invader, now abandoned them. Indeed, it seemed

1. The use of the term genocide is no longer controversial in relation to the treatment of the civilian population of Cyrenaica in the late 1920s and early 1930s. In his magnum opus on Italian colonialism, historian Nicola Labanca follows the description of the encampments, violence, illness, and hunger with a striking and quite uncharacteristically spare sentence - "Fu un genocidio." ("It was a genocide"). Labanca 2002, 175.

2. The number of 40,000 dead out of 100,000 deported emerged from official Italian documentation. A first article on the deportations was published in 1973 by Giorgio Rochat. On the controversy over the number of deaths see Wright 1969, 42 and Ahmida 2005, 44. to side with the perpetrators, as survival in the barren confines of the camps became a daily challenge and the maintenance and care of herds impossible. Escape and hiding in the open spaces surrounding the camps was likewise impossible. How is one to write an environmental history of such an event and indeed of Fascist colonial rule in Cyrenaica in the 1930s?

This article revisits the choices and outcomes of Fascist policy in Libya by foregrounding the colony's ecology. It starts with reflections on environmental historians' use of the concept of agency in constructing an integrated history of humans and the environment. It then moves on to examining the regime's determination to win a war on inhospitable terrain, the decision to set up concentration camps for the Bedouin tribes and their herds in the desert-like and semiarid areas of Cyrenaica, which in turn had a murderous effect on humans and animals. From there, it discusses the second phase of Italian policy, the "conquest of nature", when the defeat of the anticolonial resistance was followed by the agricultural reclamation of the highlands of Cyrenaica for Italian settlers. These new settlements, which at first sight seem bucolic and benign, were just as injurious to the Bedouin ecology predating the Italian occupation as were the concentration camps. In pursuing these intersections between agriculture and atrocity under Fascist rule across the Mediterranean, the article briefly considers the parallels between the regime's interventions and the recourse to concentration camps and genocide by other European colonial powers and settler societies. In the conclusion, it asks how environmental history might rewrite the story of Italian fascist interventions in the Mediterranean. While the Italians impacted the Libyan environment in massive ways, the Libyan environment, not to mention Italian perceptions of it, determined the shape and form of Italian policy. What role then can, and should, we ascribe to "nature"?

\section{Agency and the environment}

In a recent special issue of the Journal of Genocide Research, environmental historian Tim Cole reflected on what environmental history can bring to the study of the Holocaust. Expanding the 
range of actors to non-humans raises, as Cole acknowledges, "ethical" questions, requiring environmental scholars to "steer a line between making the claim that nature mattered and matters, without this being mis-read as either excusing human behaviour on the part of the perpetrators, or downplaying human experience on the part of the victims" (2020, 274). A strong tradition within environmental history has long sought to establish the "impact" the environment has had on human behavior, and that might strike one as a valuable approach also in relation to genocide, but Cole asserts that "during the Holocaust, murder and attempts to evade murder - were enacted in and through natural environments, with the natural environment playing a more active role than the language of instrumentalization or even 'impact...on conduct' would suggest" (275). Cole not only posits that the environment was exploited by perpetrators in their quest of annihilation, and at times utilized by victims to survive, but claims that the environment had a more active and independent role that needs acknowledging. Recognizing that "the environment shaped the genocide (and not only conduct during the genocide) in important ways" (275) while at the same time rejecting the notion that the environment caused genocide, Cole advocates exploring "the room between causation and instrumentalization" (276).

In mapping out the terrain of agency and impact, the existing historiography on the environment has followed two distinctive paths. Much early classic work on the environment emphasized humans' destructive impact on nature. Donald Worster's path-breaking Dust Bowl, for example, explored the interrelationship between environmental and socio-economic change, and above all the deleterious consequences of capitalist commodification (1979). Here, humans, and their misguided culture of environmental exploitation, are the agents who brought about ecological collapse. But alongside this emphasis on the human footprint, from the beginning environmental historiography has also sought to recover the "agency" of nature.

But is this to give nature too much credit? "Environmental historians", as John Herron put it, "endeavor to give the natural world agency, but antelopes - and rocks and trees and bugs and rivers can't talk" (38). The problem is not just the absence of "talk", but the elusiveness of agency, intention, and responsibility outside human actors. Debates on this question within environmental history peaked in the early 2000s and found a preliminary answer in the recognition that what needed rethinking were not so much the limits of nature's agency, as that of humans (Nash 2005). Challenging the notion of the "self-contained individual confronting an external world", Linda Nash for instance advocated history-writing where nature not only "influences and constrains human actions" but also shapes "human intentions", to arrive at the ways in which human thinking and planning emerge within the natural environment and in interaction with it (67-68). In this context, Actor Network Theory offered a helpful framework for rethinking human agency by locating it within ever-changing relationships with nonhumans and by widening the scope of "actants" inside these human-non-human networks (Latour 1993).

More recently, scientific theories of the Anthropocene were underlining how massively humans have affected the planet (though also revealing nature's power to destroy humanity $)^{3}$. Even if the Anthropocene itself is too undifferentiated and global a concept to guide historical analysis of the specific moments and processes that led to a new, manmade, geological age (Bonan 2018), scholars informed by scientific analysis have called for a radically altered understanding of what agency is and does, in order to capture the interrelationship of all things human and non-human (Iovino 2018). Worster himself has shifted emphasis, trying to find a new synthesis. Noting that "environmental historians have focused mainly on the human impact on nature", he has called on "historians [to] follow the natural sciences by taking the environment more seriously as a force in human life" (Worster 2010). This call is reflected also in efforts to root global histories in local particularities and produce studies "politicizing the received nature of our environment and bodies" and highlighting "the multiple viable ways of

3. This article cannot do justice to the massive literature on and influence of either ANT or Anthropocene-inspired theories of history. On the latter, a good place to start is Gosh 2017. 
life" and the many ways in which environmental and human change are interrelated (Thomas 2014, 1605).

Rich and valuable though these debates have been, "the 'power problem' of environmental history" (Herron 2010, 38) has not been resolved. Already in the 1990s Elizabeth Blackmar warned that environmental history risks "letting people off the hook for the history they have wrought" $(1994,4)$. The moral stakes are all the higher for historians who investigate histories of mass violence - from genocide, to slavery, colonialism, and war. How should we conceptualize the environment's role when it comes to the killing, mistreatment, and exploitation of millions? Is there any mileage in moving away from "anthropocentric thinking", when studying Fascist violence, war, and genocide? To speak with Cole, what room is there between perpetrators' "instrumentalization" of nature and nature's "causation" of atrocity?

\section{Italy's war against the anticolonial resistance}

Well before the 1911 invasion, advocates and opponents of Italy's colonial enterprise in Libya had endorsed conflicting images of the Ottoman territories of Tripolitania and Cyrenaica. Colonial activists presented Libya as a lush oriental garden; opponents labeled it a "scatolone di sabbia", a "big sandpit". Fascist propaganda later combined these two images, the sandpit and the garden, depicting Libya as a desolate but productive land awaiting the arrival of experienced and toiling Italian farmers who, like their Roman ancestors, would turn the desert into a blooming garden (Davis 2007).

First, though, the anticolonial resistance needed to be defeated. When Mussolini was appointed prime minister in 1922, he confronted a highly unstable situation in Libya. The regime took to the challenge with unrestrained violence, embroiling itself in a protracted military conflict. By 1929, the resistance seemed defeated in Tripolitania but persisted in Cyrenaica, where the Sanusiyya, a Muslim political-religious order, commanded the allegiance of local tribes and dominated the vast majority of the territory. ${ }^{4}$

To break the anticolonial resistance, the Italian forces waged an all-out war against the population by targeting the environment and its resources. The Italian forces, under Pietro Badoglio's governorship and the military command of General Rodolfo Graziani, carried out raids against civilians and their habitat. They destroyed grain stores, poisoned wells, and bombed and machine-gunned tribal camps from the air, killing people and their animals. In his memoir, Italian aviator Vincenco Biani wrote about the air attacks in Libya: "Below, a teeming mass of people fleeing in all directions, vainly looking for shelter; the earth had transformed, in an instant, into a minefield detonated by a mysterious force, one both wild and destructive. ${ }^{5}$ Biani described targeting fleeing camel herds and machine-gunning them down: "Many collapsed to the ground, exposing their obese bellies and flailing their long legs in the air, the only means for them to say they were sorry to die. But nobody mourned them. ${ }^{6}$ Nor did the Italians refrain from using mustard gas in bombarding tribal camps and oases. In a report detailing the interrogation of a prisoner, an Italian colonel noted that the prisoner recounted that "he saw many victims of the gas attacks. Many had bodies covered in sores like those caused by bad burns ... at first their bodies were covered in large blisters, which burst after a few days, leaking a colorless fluid, and leaving behind raw flesh." 7

The Italians forced one tribe after another to submit, starting with the less nomadic ones, who

4. The Sanusiyya was a Muslim religious and political order that took on a central role in the anticolonial resistance against the Italian invader. Founded in Mecca in 1837, it relocated several times and eventually established its headquarters in the oasis of Kufra. But in the late 1800s, it expanded from $\mathrm{Fez}$ to Damascus and Constantinople and into India; however, the order had arguably its greatest influence in Libya. In Cyrenaica and in the southern parts of Tripolitania, the Sanusiyya became the single most powerful political force, holding almost complete territorial sovereignty. Ali Abdullatif Ahmida has termed the Sanusiyya a "de facto state" (2005). For a different interpretation, arguing that the order positioned itself as more influential locally than it actually was, see Ryan 2018.

5. Vincenzo Biani, Ali italiane sul deserto, cited in Salerno 1979, 63.

6. Ibid., 64 .

7. Reproduced in Salerno 1979, 69. 
were more connected to the coastal towns. Not incidentally these were also the tribes that, in the words of E. E. Evans-Pritchard, the British anthropologist and expert on the Sanusiyya who in 1949 penned an influential study about the order, "lacked the forest covering of the plateau tribes and the desert wastes into which the tribes of the Sirtica could retire" (1949, 176). After submitting to the Italians, the tribes were sometimes still able to support the guerrillas. Some guerilla fighters captured by the Italians carried Italian identity cards, suggesting that they were officially registered as part of the population that had ostensibly been subdued, and as such were able to draw rations from the Italians (164). The tribes that had stopped supporting the resistance were often raided by their own fighters, making a mockery of the protection the Italians allegedly granted those who had surrendered.

In such circumstances, every Bedouin became an enemy to the Italians - or this is how the Italian leadership chose to assess the situation. In a memo to Minister of the Colonies Emilio De Bono, Governor Badoglio wrote "the population sides in every which way with the rebellion, supplying it with the means to live and fight." 8 In describing the complicated situation the Italians faced, and alluding to the brutal methods they came to employ, the perceptive anthropologist EvansPritchard resorted once again to the imagery of Cyrenaica's landscape and vegetation: "In this semi-darkness of suspicion and uncertainty, this twilight of confidence, when every human being was a foe, the friend behind no less than the enemy in front, every thicket an ambush, and every crag and boss a sniper's nest, the campaign became distorted to unreality" (1949, 165).

To interrupt any support or communication between the guerillas and the civilian population, Badoglio, in a letter to General Graziani on 20 June 1930, argued that it was necessary:

firstly, to create a broad and well-defined territorial barrier between rebelling formations and subjugated population. I am not unaware of the magnitude and gravity of such a step, which will mean the ruin of the ostensibly subjugated

8. Badoglio to De Bono, 1 July 1930, reproduced in Rochat 1981,118 population. But now our path has been set and we must follow it to the end even if the entire population of Cyrenaica should perish. It is thus imperative to concentrate the entire subjugated population in a restricted space, in order to be able to surveil it adequately and to ensure that we are in complete control of the space between them and the rebels. ${ }^{9}$

The conquerors' genocidal mindset is evident. With anything less than total victory unacceptable, the utter destruction of the enemy was not only thinkable but put into action.

A few days later, on 25 June, Graziani ordered "the complete evacuation of the Jebel with the transfer of all the populations under its first plateau, from Tolmetta to the east" (Graziani 1932, 101). The Jebel Akhdar was the most fertile area of Cyrenaica, a mountainous plateau in the northwestern part of Cyrenaica, running from Benghazi nearly $300 \mathrm{~km}$ east towards the city of Derna. It was covered in forests, and it was one of the few areas where agriculture was possible. It was mostly used as a herding ground by nomadic and semi-nomadic Bedouin tribes, though they also engaged in seasonal sowing. The climate of the Jebel is mild and generally warm and temperate. Rain falls mostly in the winter, with relatively little rain in the summer. The average temperature in Bayda, the major city of the Jebel, is $15.3^{\circ} \mathrm{C}$ and the yearly rainfall is around $540 \mathrm{~mm}$. The Köppen-Geiger classification categorizes the climate here as Mediterranean or dry summer climate (Csc). By contrast, the area to which the people of the Jebel were eventually evacuated was desertic.

The Italians initially concentrated the seminomadic and nomadic population not too far from their habitual ranges, below the first plateau of the Jebel closer to the shore - an area more eroded, drier, and less fertile than the upper planes. Reporting on this first concentration of civilians in the inhospitable periphery of the settled, administrative centers of northwestern Cyrenaica underway in early July 1930, Badoglio gleefully informed De Bono that "the entire population has been suffused with a sense of true dismay and

9. Reproduced in Rochat 1981, 116-117. My emphasis. 
disorientation." ${ }^{10}$ Then, following decisions made in late August to further increase the distance between the tribes and the fighters, the majority of the concentrated populations were moved again in the fall and winter to the Sirtica desert between Benghazi and el-Agheila in the Gulf of Sidra in western Cyrenaica (Rochat 1981, 125).

The camp at el-Agheila (al-'Uqaylah) at the southern end of the Gulf of Sidra held 34,500 prisoners and was mostly reserved for the families and relatives of resistance fighters; the nearby camp at Marsa al Brega (Marsã al Burayqah) held 20,000 prisoners. $^{11}$ With an average temperature of $20.9^{\circ} \mathrm{C}$ (and an August average of $26.7^{\circ} \mathrm{C}$ ) and an annual rainfall of $143 \mathrm{~mm}$, the climate there is classified as hot desert (BWh). ${ }^{12}$ The next two camps in terms of size, Soluch (Suluq) with 20,000 prisoners and Sidi Ahmed el-Magrun (El Magrun) with 13,000 prisoners were located south of Benghazi, in the semiarid regions of southwestern Cyrenaica, where the climate is classified as hot semiarid steppe (BSh) with an average annual temperature of $20.4^{\circ} \mathrm{C}$ and an annual rainfall of $257 \mathrm{~mm} .{ }^{13}$ For the prisoners, the camps represented a drastically altered relationship to the environment and its characteristics, as they were moved from a dry Mediterranean climate to a desertic and semiarid one.

About 100,000 people, that is two thirds of the civilian population still in Cyrenaica (many had already fled the violence to Egypt), were eventually rounded up and sent to one of the 16 concentration camps in northwestern Cyrenaica and the Sirtica desert (Ahmida 2021, Ebner 2018, Ottolenghi 1997, Salerno 1979). To arrive at the camps, the populations endured long and exhausting marches and many died or were killed in transit. For the survivors, the experience was one of displacement, forced confinement, and physical and mental suffering.

10. Bagoglio to De Bono, 7 July 1930, reproduced in Rochat $1981,121$.

11. The numbers of camp prisoners are from the website "I campi fascisti. Dalle guerre in Africa alla Repubblica di Salò": http://campifascisti.it/pagina.php?id_pag=1 (last accessed 12/22/2020).

12. The climate data is for neighboring Ajdabiya which lies further inland: https://en.climate-data.org/africa/libya/alwahat/ajdabiya-3456/ (last accessed 12/22/2020).

13. https://en.climate-data.org/africa/libya/benghazi/ benghazi-550/ (last accessed 12/22/2020).
General Graziani did not mince words when he described the camps: "all camps were surrounded by double barbed wire; food rationed; pastures restricted and controlled; external movement limited to special permits." The tribes, he added, were subject to "measures of extreme severity, delivered without compunction or mercy, that rained down on them inexorably" (1932, 104). Noting that the tribes initially had been allowed to graze their herds freely, Graziani contended that it had been necessary to restrain such habits in order to avoid the herds falling into rebel hands. The government was ready "to act in cold blood and reduce the populations to the most wretched hunger if they do not submit once and for all to our orders" (105). Malnutrition and illness were widespread. Tribal herds were wiped out. To survive, the prisoners were forced to work for the Italians, mainly in road and railroad construction.

The camps clearly were an act of war; they were a strategy to defeat the resistance. As anthropologist Evans-Pritchard later explained, "the Italians were fighting a people, not an army, and a people can be defeated only by total imprisonment or extermination" (171).

\section{The camps}

The camps transformed the desert into a prison and weaponized Libya's ecology against its autochthonous population. The Libyan resistance fighters had been using their knowledge of the territory against the Italian invaders, engaging them in skirmishes and then dispersing and hiding in their natural habitat. The Italians had felt constantly at a disadvantage because of their enemies' knowledge of the terrain and their refusal to face the Italians in open battle in the Jebel Akhdar, the stronghold of the Sanusiyya. This is how Badoglio described 'Umar al-Mukhtar, the leader of the resistance, and his fighters, in a memo to De Bono: "A perfect knowledge of the territory, especially of the vast forested area and the wadis of the highland, favors them in every move. His tribesmen are people who for years have not engaged in any other profession than that of the rebel. They are by now used to this life of adventure, vagrancy, and fighting, ennobled by 
the halo of heroism." ${ }^{14}$ No doubt, there is a certain romantic vision of the rebel built into Badoglio's assessment, but he correctly identified the ways in which knowledge of the topography aided the local guerilla fighters not least because the terrain made mechanized warfare impossible.

The Bedouins were in fact fighting in small bands of at most 100-300 men. Evans-Pritchard estimated that toward the end of the war the active guerrillas never numbered more than 600700 men at any one moment (169). The bands were organized by tribes and were refurbished with men by each tribe, but they also could include men from other tribes, and even men from outside Cyrenaica who had come to fight the European infidel. The bands were small and mobile, attacking incessantly but unpredictably, and relying on surprise and speed. Again EvansPritchard provides a good sense of what this meant for their opponents. For the Italians, he wrote, "there were no fixed points of opposition. It was indefinite and disseminated" (171). Or, even more pointedly: "The enemy was ... protean and ubiquitous. It was like fighting mosquitoes. They have to be killed one by one and there are always a few left. Next sunset they are back again in the same numbers as before" (180). "The rebellion was like a fire creeping deceitfully over the whole of the vast territory of the Colony" (172).

After the establishment of the camps, it was the conquerors who would break the resistance by using the landscape to their advantage. From the wadis, crags, and forests of the Jebel Akhdar, the regime moved the civilians to the openness of the desert: no place to let the herds graze, no place to meet and aid the fighters, no place to hide if escape was attempted. The opening stanzas from the poem "No Illness But This Place" by Rajab Hamad Buhwaish al-Minifi, interned in the El-Agheila camp, render the hardship of displacement. Given that the poem is one of the few primary sources from the prisoners, it deserves to be quoted at length:

14. Badoglio to De Bono, 1 July 1930, reproduced in Rochat 1981, 118.
I have no illness but this place of Egaila,

the imprisonment of my tribe

and separation from my kin's abode.

No illness but endless grief

meager provisions

and the loss of my black red-spotted steed

Who,when strife broke, stretched her solid-flesh neck, impossible to describe,

her peer does not exist.

I have no illness except my threadbare state

and this unbearable longing

for Aakrama, Adama and Sgaif,

And for the pastures Lafwat, best of places,

which, even when parched

bursts grass green for the herds.

I long for Aakrama and Sarrati,

I wish I were there now.

I'll be grateful to reach them alive. ${ }^{15}$

The stanzas powerfully convey the longing for a lost ecology, one where land, animals, and humans coexisted peacefully and productively.

The camps, at least in so far as we have pictorial documentation, conform to the architype of concentration camps - well-ordered rows of bare dwellings, in this case tents, in otherwise empty, desolate land. An Italian medical doctor's description captures the attitudes that helped bring the camps into being, paradoxically inverting what was life-giving and what was deadly. Before the native population had been coerced into the camps, he wrote, their "typical tents of goat and camel wool," "hidden along the ridges of the Jebel and punctuating the cavities of the Marmarica region and the basins of the pre-desert" had been the "living caskets of an untamed people, and impediments to the expression of the most civilized peoples." But now, he claimed, the "endless lines" of the tents in the camps "align under the flaming sun of the desert, almost blueprints of future cities." ${ }^{16}$ In capturing the shift from the Jebel of ridges, cavities, and basins to the flaming sun of the desert, he hinted at future settlements in

15. https://www.jadaliyya.com/Details/23985/RajabBuhwaysh,-No-Illness-But-This-Place (last accessed $12 / 22 / 2020)$.

16. Dr. Tedeschi from Derna quoted in Graziani 1932, 117. 
this most inhospitable of environments (on which more in a moment). He managed to imply that the nomadic lives of the tribes had been somehow deathly, and that the dead zones of the tents in the camps presaged the civilization to come.

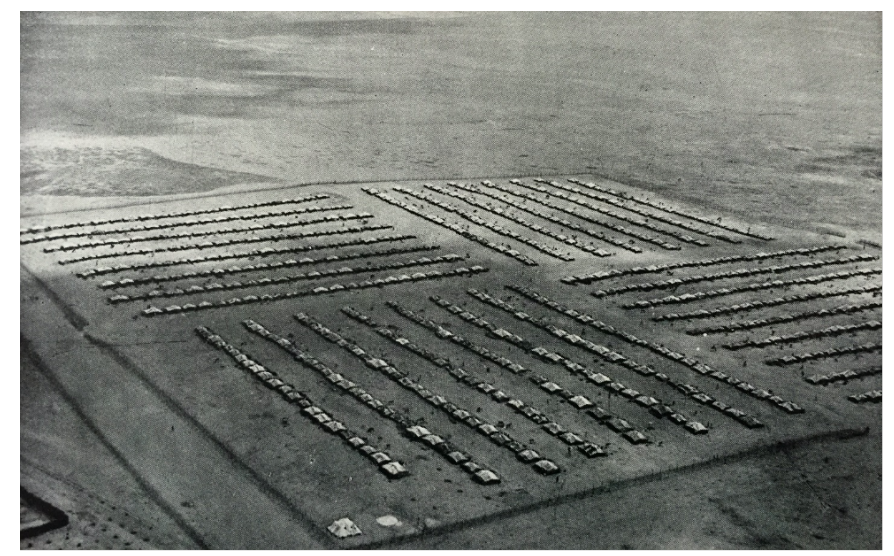

Figure 1: El Abiar concentration camp (Rodolfo Graziani, Cirenaica pacificata, Mondadori, 1932).

To the gaze of the perpetrator who photographed them from above, the camps presented themselves as ordered and disciplined. At the time, the aerial view was establishing itself as a new form of domination of the landscape - for reconnaissance, for terror bombing, but also as an all-knowing, all-encompassing view. But while the perpetrators were indeed free to take aerial photographs of the sites they had created, the sense of omnipresence and omniscience that such images created was an illusion. The aerial panopticon captured what was in fact a response to a reality far short of total control. Moreover, the apparently modernist operation, orderly and efficient, was anything but; the seeming orderliness of the aerial view hid extraordinary misery below.

Crossing Libya from Tunisia to Egypt in 1930, Danish traveler Knud Holmboe met a group of prisoners in an early Italian concentration camp near Sirte. "Never have I seen such poverty", he wrote. "The women had only torn rags wrapped around them, and the men looked just as bad. Starved children came running up, begging for coins" (Holmboe 1937, 87). Holmboe also described an early concentration camp near Merj, between Benghazi and Darnah, which he travelled through in late April/early May. At that point, the order of mass concentration camps had not yet been given, but some subjugated tribes had already been relocated, concentrated, and their movements confined and controlled:

The camp was immense. It contained at least fifteen hundred tents and had a population of six to eight thousand people. It was fenced in with barbed wire, and there were guards with machine guns at every entrance... The Bedouins gathered around us. They looked incredibly ragged... Many of them seemed ill and wretched, limping along with crooked backs, or with arms and legs that were terribly deformed (191-192).

Prisoners suffered from hunger and deprivation. There was little to no sanitation or medical assistance. There were punishments and executions. Again, a few stanzas from Rajab Hamad Buhwaish al-Minifi offer a sense of the prisoners' experience:

I have no illness except the hearing of abuse denial of pleas

and the loss of those who were once eminent.

And women laid down naked, stripped

for the least of causes

trampled and ravished, acts no words deign describe.

No illness except the saying of "Beat them"

"No pardon"

and "With the sword extract their labor",

thronged in the company of strangers,

a base living -

except for God's help, my hands' cunning stripped.

No illness but the swallowing of hardship my imagination pining

for our horses, sheep, beasts of burden. ${ }^{17}$

As already noted, between 50,000 and 70,000 people died in the camps. The animals in their care perished in extraordinary numbers, too. The inmates were forbidden from allowing their animals to graze freely - doing so was seen as an act of passive resistance and the animals confiscated and sold. Historian Giorgio Rochat reports with some confidence that $90-95 \%$ of goat, sheep, and

17. https://www.jadaliyya.com/Details/23985/RajabBuhwaysh,-No-Illness-But-This-Place (last accessed $12 / 22 / 2020)$. 
horses died and perhaps $80 \%$ of cattle and camels (1981, 161).

Italy's fight against the Sanusiyya and the people of Cyrenaica was far from the only colonial conflict against local guerrillas in the late 19th and early 20th century that saw European forces imprisoning the local population in camps. Recent scholarship has emphasized the ways in which the "imperial cloud" of the European powers included lessons about the use of camps (Forth and Kreienbaum 2016). The Italian genocide in Libya was little different from actions perpetrated by other western powers, starting with the concentration of civilians in 1896 in the Spanish war against Cuban insurgents, continuing with the forced transfer of civilians to camps by the Americans in the Philippines in 1901, of the Boers by the British in South Africa around the same time, and of Africans by the Germans in South-West Africa a few years later (Pitzer 2017). Appalling as the genocide perpetrated against the Bedouin tribes of Cyrenaica is, what the Italians were doing was not all that different from other, similar atrocities perpetrated by modern colonizers in similar situations of armed resistance in harsh, difficult climates and challenging topographies (Lal 2005). Though not specifically citing the examples above, Graziani noted that when he had doubts about the cruelty imposed, he remembered that other Europeans had already done the same: "...as far as colonial conquest goes", Graziani remarked, "there was nothing new to learn". (1932, 110). He furthermore referred to classical Roman examples of Caesar and Tacitus and to Machiavelli's Prince to justify the ruthless treatment of the "rebels".

What Graziani and other colonizers had recognized, whether explicitly or implicitly, was the interconnectedness of humans and their habitat. They understood that an effective way of defeating the rebellion was to break that link. And they generally understood the genocidal consequences of such a course of action, as Badoglio's readiness to accept the demise of "the entire population of Cyrenaica" attests. They could have chosen other solutions - they could have deescalated, negotiated, retracted - but did not do so. To emphasize that point it is worthwhile noting that not all colonial overlords were ready to go the route of uncompromising warfare against civilians. In her global history of concentration camps, Andrea Pitzer points out that the Spanish Governor of Cuba Arsenio Martínez-Campos recognized how effectively concentration camps might contribute to defeating the Cuban insurgence in the late 1900s, but refused to employ them. After he was recalled to Spain, his replacement, Captain General Valeriano Weyler, had no such compunction (Pitzer 2017, 28-29). In Libya, five different governors fought the resistance between 1923 and 1933 but only Badoglio, and his deputy Graziani, decided to imprison the civilian population, well aware of the costs in human and animal life. It is hard to know if Graziani was fooling anyone when in a meeting with journalists in Benghazi in June 1931, he claimed that just as the Bedouins "lived before under a tent with their herds, so they live now in the new encampments". ${ }^{18}$ He further specified that the camps were not "concentration camps as such" because they did not collect people who lived in permanent settlements; rather, the undertaking was a "mere movement of nomadic populations which in the new home retain their life habits, even if circumscribed and controlled". Not only that, he concluded, in their new homes they could better take advantage of the state's economic and sanitary assistance.

The camps proved the winning strategy in Italy's war against the resistance. Weakened by the internment of civilians, the anticolonial struggle was dealt the final blow by the death of its leader 'Umar al-Mukhtar, whom the Italians seized and publicly hanged in September 1931. For a brief moment it looked as if the camps might become a permanent solution to maintaining Italian control over Cyrenaica, thereby recalling the assessment of the medical doctor who had envisioned the camps as "blueprints for future cities". In July1932 Badoglio charted the course of action for Graziani, which among its seven points included the following: "Give every active attention to the concentration camps so that they can be maintained without difficulty and the native convinces himself, or better grows accustomed, to considering that as his permanent location. Help tie them to the land with the construction of

18. Graziani quoted in Rochat 1981, 169-170. 
housing and the assignment of landholdings". ${ }^{19}$ The vision that Badoglio outlined was one of native reserves established in a different natural environment than the one to which the indigenous population was habituated, and one based on an entirely new relationship of the population to the land.

At the time of Badoglio's writing, however, some camps were already being demobilized. The continued imprisonment of the relatives of exiled sheiks who themselves had been pardoned and released was no longer tenable. Moreover, in the case of the Soluch camp, widespread contagious disease made it expedient to break up the camp once the resistance was crushed. Maintaining permanent settlements in those taxing environmental conditions was entirely unrealistic. The desert environment, which had aided the Italians in subjugating the tribes, now upended the Fascist plans, as it could not serve as a permanent reservation for the nomad population. Moreover, the camp population represented a much needed and cheap labor force for the planned Italian agricultural settlement projects in the Jebel, even though local police forces and the small Italian population of Cyrenaica was entirely against a return of the imprisoned tribes (Rochat 1981, 176). Thus, in 1932 and 1933, the population was released from the concentration camps.

Yet the violation of the people and their habitat did not end with the concentration camps. When the survivors of the camps were released, they were encouraged to disperse. They could not, however, return to the Jebel Akhdar, Cyrenaica's most fertile area, where the Italian state was about to start a colonization program for Italian peasants. The tribes were expected to live off their herds in the steppe sloping toward the desert and on the narrow, semiarid coastal belt, with restricted passageways between these two areas through the more productive lands reserved for Italian settlement.

\section{From camps to villages}

Much has been made of the relationship between the concentration camps and the agricultural set-

19. Badoglio to Graziani, 29 July 1932, reproduced in Rochat 1981, 173. tlement program. Because Fascist violence towards Libya's native population is reminiscent of settler colonialism's exterminatory warfare in other parts of the world (Veracini 2010, Gott 2007, Wolfe 2006, Krautwurst 2003), it might seem plausible that here, too, a grab for settler land resulted in the brutal submission and dislocation of the native population. However, the dearth of settlers ready to take possession of the land and the central role of the motherland in the persecution of the native population should give us pause before making hasty conclusions about a "logic of elimination" (Wolfe 2006, 387) driving also Italian settler colonialism. In Libya, settlers were not so much the cause of war and genocide as their consequence. The concentration camps, and the ensuing genocide, were a means to break the anticolonial resistance. They were a last-ditch attempt to win a war that had been confounding the Italian army for years. Mass settlement was hardly on the cards when the decision to displace the native population was made.

Though hailed as a destination for Italy's landless peasants already before the 1911 invasion, the Italian government over the following decades had in fact made few provisions for settlers. This is as true of Italy's liberal governments as of the Fascist regime. When Mussolini visited Libya in 1926, he praised the pioneering spirit of Italian colonizers, but none of his public speeches pictured Libya as a mass destination for struggling Italians or envisaged a mass settlement program of the kind that would be implemented in the late 1930s (Pergher 2018, 50). As we will see, when the settlement program eventually was set in motion, it was a response less to the demographic needs of the motherland than to the security needs of a recalcitrant colony.

For the chief military commander Graziani, the core goal, something he insisted on repeatedly, was to secure Italian domination: "the territory's security and peacefulness" had to be "protected above all other considerations" (122). He believed Italy needed to control the territory directly, rather than via alliances with local leaders and proxies, who could not be trusted. To him, the nomadic and semi-nomadic populations of Cyrenaica constituted an "imminent danger" (122): "Rejecting every kind of discipline, accustomed to 
roam in often immense and desertic territories, strengthened by their mobility and ease of relocation, suffused by the mystique of independence, always ready for war and looting, the nomads have always reacted against any government imposition" (120). The Bedouins were thus not given free reign even after the resistance was crushed. On the contrary, Graziani deemed it "necessary to rigorously and forever control and curb" their movements and delimit their territory, which, most importantly, should not include the one area that could support some agriculture, and thus the settlement of Italians, namely the Jebel Akhdar (122). Comparing the "the nomads' passage" to "that of a destructive swarm of locusts" (123), Graziani believed they needed to be "forever excluded" from the Jebel and confined to predesertic areas, "making room for the thousands and thousands of Italian peasants" (123). Rather than recognizing the nomadism of the Bedouins as a necessary adaptation to the environment they inhabited, Graziani saw them as the cause of an environment he deemed infertile and inhospitable. This line of reasoning was a recurrent trope in European thinking, as was Graziani's prejudice against nomads as a security threat. (Isenberg, Morrissey, and Warren 2019; Atkinson 2000).

To solve the security problem both in Tripolitania and Cyrenaica, Italian authorities came to see the settlement of large numbers of Italian landholding families as the preferred option. Already in 1928, when the resistance had been defeated in Tripolitania but not yet in Cyrenaica, the general secretary of Tripolitania, Maurizio Rava, maintained that settlement of the metropolitan population would mean "absolute security forever" (1928, 214). In 1932, when the resistance was at long last defeated also in Cyrenaica, Alessandro Lessona, then undersecretary of the Ministry for the Colonies explained in Fascism's foremost journal Gerarchia that "demographic colonization" would be the "means" to assert Cyreanica's "Italianness" in the aftermath of the war against the Sanusiyya $(1932,268)$.

Before the Italian invasion, local arrangements of land use in Cyrenaica involved nomadic herding of livestock, dispersed sowing of seasonal crops, and gardening of small plots in oases. There were no large commercial farming enterprises. Most of the land was held communally rather than owned privately. No doubt the Italians desired to exploit the colonies of Tripolitania and Cyrenaica from the beginning, but initially they sought to establish large estates employing native labor. ${ }^{20}$ During the 1910s and 1920s, few Italians settled in Cyrenaica, and even fewer entrepreneurs invested in agriculture due to the ongoing war against the Sanusiyya. Shortly after the resistance was defeated, the Superior Colonial Council described a vast land expanse in Cyrenaica to be given to an Italian officer: "In the entire region there is no enclosed land; now and then the natives sow negligible quantities of barley. However, the raising of livestock, in particular sheep, holds the greatest importance. There is no permanent population" ${ }^{21}$

Though regime propaganda praised Libya as the solution to Italy's presumed overpopulation problem, agronomists recognized that the colony could not fulfill that role. Already in 1927, Armando Maugini, who in due course became one of the regime's key consultants in the colonization program, had reflected on a possible settlement plan and clarified its purpose. ${ }^{22}$ To him, Libya and that included the yet-to-be-subjugated Cyrenaica - could not offer a meaningful outlet for Italy's landless masses; other lands would have to fulfill that purpose. The regime's task, rather, lay in securing Italian rule in North Africa. Political and military authority would not suffice to hold the colony; Italians would need to live there: "we need to populate it rapidly, put the colony on a firm footing, and hasten the conquest of the land" (Maugini 1927, 154). Maugini's hope was that the highlands of Cyrenaica would eventually provide work and prosperity for at least 100,000 Italians (148), who through their presence would safeguard Italian sovereignty. His colleague Filippo Cavazza went a step further, arguing that Italian settlers would not just secure

20. Archivio Storico Diplomatico del Ministero degli Affari Esteri (ASDMAE), Archivio Storico Ministero Africa Italiana (ASMAI), III, Opere Pubbliche, b. 73, fascicolo (f.) Colonizzazione della Cirenaica: "La colonizzazione e la valorizzazione agraria".

21. ASDMAE, ASMAI, Consiglio Superiore Coloniale (192339), busta (b.) 17, seconda sezione, n. 27, 23 April 1934.

22. Maugini was an agronomist and tropicalist who starting in 1924 directed the Istituto agricolo coloniale italiano (Italian Agricultural Colonial Institute) for forty years. 
but in fact transform the North African colonies of Cyrenaica and Tripolitania: "Nobody can fail to recognize how much more Italian Tripolitania will be the day that, in addition to the 50,000 natives, 100,000 industrious Italian citizens will live there" (Cavazza 1927, 78). By "counterbalancing" the indigenous population, Italian settlers would at last secure the territory for Italy (78). In a new world premised on the idea of national sovereignty, the regime believed that in the long run cementing sovereignty and quelling any type of insurgence required the presence of large numbers of Italian settlers outnumbering the native population (Pergher 2018).

It was only in 1928, when agronomists and colonial administrators started to see settlement as a way to hold on to the colony, that a new law bound concessions of public land to private entrepreneurs to the hiring and settlement of Italian families. ${ }^{23}$ The next step in the state's commitment to fostering the immigration and settlement of Italian farmers was a 1932 decree establishing the Agency for the Colonization of Cyrenaica (Ente per la colonizzazione della Cirenaica, ECC), under the charge of the Commission for Migration and Internal Colonization (Commissariato per le Migrazioni e la Colonizzazione Interna) and the Ministry for the Colonies, and financed by various state institutions and private banks. The agency was to succeed where wealthy landowners had dragged their feet: bringing Italian families to Libya. In his speech to parliament, Mussolini anticipated great possibilities in "underpopulated" Libyan territories. Passing over in silence the role that concentration camps had played in creating that underpopulation, he described the land in glowing terms as ripe for "orderly waves of colonists" who in the "shortest time possible" were to become the "owners and citizens of what must become a new Italian region". ${ }^{24}$

In 1934 the ECC extended its activity to Tripolitania. It was now renamed Agency for the Colonization of Libya (Ente per la Colonizzazione della Libia). In that same year, the Fascist National Social Security Administration

23. Law 7 June 1928, n. 1695 and law 29 July 1928, n. 2433.

24. Archivio Centrale dello Stato, Presidenza del Consiglio dei Ministri 34-36, f. 17/1/842, sottofascicolo 5: 17 November 1932 .
(Istituto Nazionale Fascista della Previdenza Sociale, INFPS) also took on an active role in the Libyan settlement program. The creation of the ECL and the empowerment of the INFPS marked a radical change in pace and style of land management in Libya. ${ }^{25}$ The colonial government, which had previously limited its activity to acquiring government property and granting land to entrepreneurs, devised and coordinated an increasingly ambitious state-financed settlement program. After the government handed over public land at no cost to the two institutions, they carved it up and planned villages and individual family farmsteads ranging from 15 to 30 hectares in size. While the government built roads and dug wells, the ECL and INFPS financed and oversaw the construction of villages and farmsteads. Each farm was equipped with tools, furniture, animals, seeds, and food stocks. As Evan Pritchard put it, "in this smiling country of the juniper, the lentisk, and cypress began to spring up the little white Italian farms" (219). These new efforts, however, only yielded four villages of barely 300 families in Cyrenaica, of whom a considerable number requested repatriation soon after their arrival. ${ }^{26}$

Then, in 1937 the state became more directly involved in financing the settlement program. In what was termed a project of "intensive demographic colonization" (colonizzazione demografica intensiva), the state not only provided land and infrastructure as before but also granted subsidies and favorable government loans to the ECL and the INFPS for the construction of additional villages. Thirty percent of the reclamation costs were borne by a state subsidy that was credited entirely to the settlers; the remaining seventy percent were covered by a favorable state loan. More than twenty villages were built across the coastal areas of Tripolitania and Cyrenaica and named after the "heroes" and "martyrs" of the Risorgimento and of Fascism. Each village had a center with a church,

25. On the settlement program, see Pergher 2018, Cresti 2011, Cresti 1996, Segrè 1974.

26. By the end of 1937, these early state-supported settlement programs, however, remained rather small-scale and yielded meager results, counting about 7,000 settlers dispersed in 2 villages with nearly 250 farmsteads in Tripolitania and 4 villages of just short 300 families in Cyrenaica (Cresti 2011, 149-150). On the difficulties and setbacks of the early program, see Cresti 2005 . 
Fascist Party building, school, and store grouped around a piazza - resembling the agricultural centers of the Agro Pontino, where Fascism had launched its most renowned internal land reclamation and resettlement program (Caprotti and Kaïka 2008, Stampacchia 2000, Folchi 2000). The farmhouses were built on the land plots assigned to each farm, dotting the landscape and quite a distance from the village centers. The setup was thus quite different from the Italian regions where many of the settlers originated, where the farmers lived in the village and often covered some distance to arrive at their fields.

With their churches and schools, the villages were planned to be inhabited by complete family units rather than individuals. The program in fact foresaw the recruitment of families with at least two adult sons able to work the farmstead. ${ }^{27}$ By transporting entire families, the regime aimed to create instant, settled Italian communities. The hope was that settlers would immediately feel at home in Libya and not contemplate return migration. Rooting settlers permanently was in turn seen as crucial in meeting the authorities' prime objective of asserting Italian dominion. As the president of one of the settlement agencies explained, "the entire coastal area must be transformed into a prevalently Italian area, in which the Arabs will be reduced to an increasingly negligible minority, by withdrawing little by little toward the interior". ${ }^{28}$ The project foresaw the settlement of one hundred thousand Italians in the course of just five years. The ultimate goal was the relocation of half a million Italians.

The rigid regulation of the settlers' lives was meant to strengthen their tie to the land and farmstead. Fascist policy prohibited family members from seeking employment off the farm, while also excluding all use of indigenous labor on the farm. The state was thus seeking to control family behavior and determine the division of labor within the "frontier" household. After all, the state had made a huge investment, and the settlers

27. Archivio Storico Istituto Nazionale per la Previdenza Sociale, Carte Colonizzazione Libica, f. 21: Report by the Office for Insurance and Unemployment, no author, n.d.

28. Archivio Storico dell'Istituto Nazionale per la Previdenza Sociale, Carte della colonizzazione libica, f. 129: Meeting 30 July 1937. had to repay what appeared to already belong to them; in fact, the farm would become their property only after 30 years of hard labor (Palloni 1945). This was a much more managed approach to settlement than most western powers who sent settlers to their borderlands had adopted in the past. ${ }^{29}$ They had generally not made the family the mandatory unit of settlement, nor had they given such generous subsidies.

This tightly managed program also involved the creation of new territorial demarcations and barriers. In planning the colonization of Cyrenaica, Governor Italo Balbo followed Graziani in believing that settlement went hand in hand with a clear policy of segregation. Only the Italians would inhabit the highlands of the Jebel Akhdar, "so that not a palm of the 'Green Mountain' [would] escape us". ${ }^{30}$ The Bedouin tribes were restricted to the northern and southern fringes of the fertile Jebel that had been their former heartland. As Evans-Pritchard remarked, "all that was left to them in northern Cyrenaica were the narrow coastal belt, the more rugged parts of the first terrace which would not yield to Italian methods of cultivation, and the bleak southern slopes of the plateau" (199). Circumscribed corridors across the plateau enabled the Bedouins and their herds to transit between the two areas. Thus, even after the camps were cleared, land use continued to limit the native population's freedom of movement and excluded it from what was to be Italian-dominated space. Indeed, the new arrangement threatened the Bedouins' existence. Without access to the more fertile highlands of the Jebel Akhdar, it would take only a year of drought to make survival in the two semiarid areas assigned to them untenable. As with the camps, the Italians' spatial policy was once again creating a situation in which "nature" would inevitably turn against the native population.

29. For other settler colonial projects, see Cavanagh and Veracini 2017.

30. ASMAE, ASMAI, Gabinetto archivio segreto, b. 70, f. Colonizzazione demografica in Libia: Balbo report on the reclamation work in Cyrenaica, 4 August 1938. 


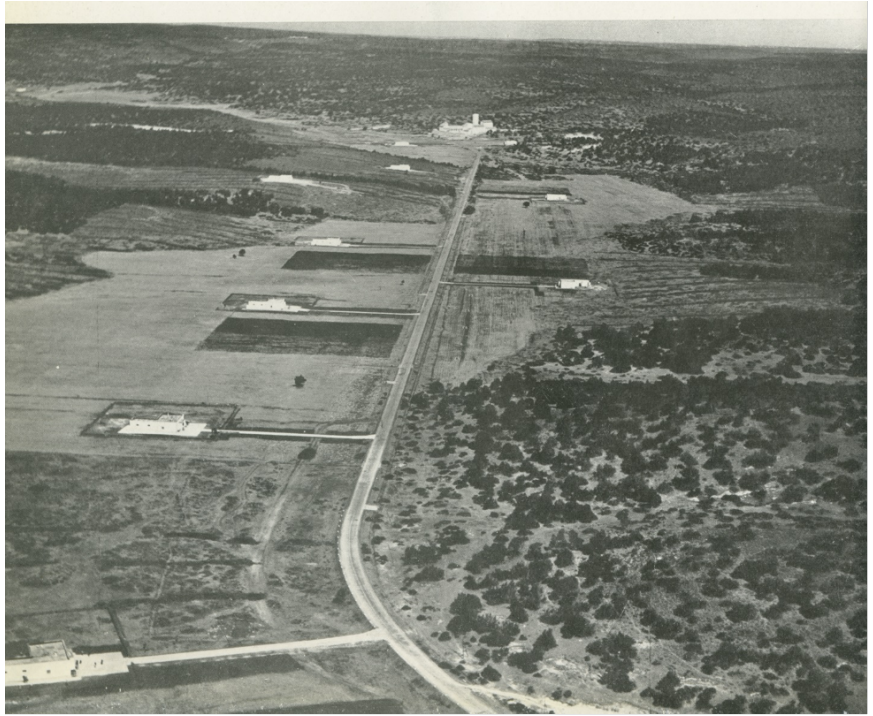

Figure 2: Motorway "Litoranea libica" and D'Annunzio village (I Ventimila. Documentario fotografico della prima migrazione di massa di coloni in Libia per il piano di colonizzazione demografica intensiva Anno XVII-1938, Tripoli 1939).

As with the concentration camps, also here it is the aerial images that provide the most extended and dominant view of the Italian intervention on the territory. From above, the agricultural centers and farmsteads seem to indicate an orderly and coordinated use of an otherwise "virgin" territory: to the colonizer's eye the land was empty, uncultivated, and unused. The centers looked modern, well-ordered, efficient, and their white-washed walls sparkled in the North African sun. Yet once again the aerial image is an illusion. The pictures of the gleaming new settlement villages belied a fertile land that nonetheless was not suited for intensive cultivation. Tied to a fallacious interpretation of ancient Roman history, which envisioned Libya as the empire's breadbasket, regime propaganda portrayed dormant fields in need of laborious Italian migrants (Munzi 2001). But this mega project, like so many others of its kind, was built on misconceptions about the environment and the ways in which humans could thrive long-term in particular climates and terrains.

\section{Conclusion}

In this condensed account of Fascist actions in Libya, the environment has played a significant role. The Fascists saw Libyan land as unproductive, and its people as poor husbands of the soil. They harnessed the desert environment to crush the resistance, and they profoundly altered the ecology of the highlands to ready them for Italian settlers. But how exactly should we assess the role of the environment in the genocide and the settlement program?

In reflecting on the transformation of Germany's waterways and landscape from the eighteenth century to the present, David Blackbourn noted that "the human domination of nature has a lot to tell us about the nature of human domination" (2006, 7). An approach that seeks to explore assertions of power through the analysis of environmental practices, policies, and discourses lends itself well for the study of Italian fascism, both in the metropole and the colonies. As environmental historians have shown, the Fascists sought to manage, manipulate, and harness nature in the interest of the nation, the race, and the economy (Armiero and Hardenberg 2013). Fascist discourses and policies in relation to nature betray the regime's megalomania, its obsession with conquest, its uncompromising attitude as well as the limitations to knowledge, understanding, and funding that often thwarted Fascist projects. Libya offers a powerful example of all this. The regime intervened forcefully and violently in the ecology of the Jebel Akhdar, removing and interning its inhabitants and bringing in settlers to establish an agricultural society that was supposed to embody past bucolic virtues and yet was modern in its outsized planning, employment of machinery, and utter destruction of the native environment.

Important as this kind of "impact" analysis is, it leaves agency firmly in human hands. Thinking in terms of Tim Cole's spectrum of "instrumentalization - causation", it sticks very much to the former end, laying out how the regime instrumentalized, misunderstood, and misused the environment for its own goals. Yet "nature" was never merely an instrument of policy. As this short overview of the genocide and the settlement program has shown, the environment influenced intentions, outlooks, and choices. While it did not determine Fascist policy, it constrained and shaped the options open to the regime. To use 
Linda Nash's framework, Fascist thinking and planning emerged within a particular environment and in interaction with it - or perhaps we should say from within one particular environment and in interaction with another. For, the Fascists' approach was shaped as much by notions of fecundity and barrenness, of waste and exploitation that they brought with them to Libya, based on their experiences in a very different kind of environment back home. Their lack of understanding of local conditions, first and foremost the logic of a nomadic and semi-nomadic lifestyle in this environment, helped to exacerbate the impact of their policies, as did their general willingness to overreach. These characteristics in turn reflected a general sense of colonial superiority, and also an inability to recognize and yield to nature's power - a modernist hubris that seems to have afflicted western countries especially in unknown and misunderstood colonial lands.

For all that, it remains fair to say that the environment was a key factor in the Italian inability to crush the resistance in Cyrenaica with traditional warfare. The difficult terrain made guerilla warfare possible and mechanized warfare and deployment of large armies impracticable. The Italians' perception that "nature" was siding with the resistance in turn dictated their actions. Graziani's ruthless strategy mobilized the environment against the resistance. In short, environmental history enables us to provide a fuller, more realistic picture of the Fascist conflict in Libya and what it meant for all human and nonhuman actants involved (Armiero 2008). Most importantly, it helps us get a clearer and more differentiated sense of the indigenous population's experience of the camps, of the transformation of their habitual grazing and sowing lands into Italian agricultural enterprises, and of their residual existence after defeat and expulsion by the Italians. Much work remains to be done in that respect. For instance, how did the decimated herds recover after the genocide? What did spatial confinement to the narrow, arid coastal belt and the pre-desertic slopes of the Jebel toward the Sahara mean for the surviving Bedouins? And given that the Italians were defeated by the Allies a mere 10 years after the beginnings of the colonization program and most settlers left the colony after the war (with the last few expelled by Muammar al-Gaddafi in 1970), what happened to the trees the Italians had planted, the fields they had tilled, and the wells and drains they had dug? That the Italian settlements were heading for trouble was apparent already in the first few years, when drought made it difficult to farm (Biasillo and da Silva 2019,167168). But we need to learn more about how the ecology of the Jebel Akhdar changed following the Fascist intervention.

Aside from the important empirical work that undoubtedly needs doing, the question of how to allot "agency" remains a moral one. Can and should we see the environment as cause or as agent? In recent historiography, historians have often invoked the notion of agency in an effort to give voice to the subaltern and thus to right, ever so slightly, some of the wrongs of the past. It has thus become a moral endeavor as much as an analytical one, an effort to recover the experiences of those to whom harm was done or who have been silenced. Such usage challenges the image of the passive or powerless victim, but it does not seek to remove responsibility from the perpetrator. When we turn to the environment, however, and ask about its agency, that kind of usage no longer feels quite so apposite. To talk of an agentic environment surely makes sense only if we are claiming that the environment has real power and determining (or co-determining) human behavior and outcomes. But that in turn reminds us of Elizabeth Blackmar's concern from the 1990s. Do we really want to let the Fascists "off the hook for the history they have wrought" (Blackmar 1994, 4)?

If historians of Fascism have for the most part focused on the "impact" on the environment rather than the environment's "agency", then probably because this reflected the moral and political impulses of the historiography. The same decades since the 1980s which saw the discipline of history begin to discover the power of the environment over mankind, were also the ones in which historians of Fascism were most committed to demonstrating the regime's responsibility and culpability. The priority was to rebut claims that the regime was harmless or beneficial and establish beyond argument how murderous and violent it had been. Some historians focused on the regime 
as such, others on the Italian people more broadly, but the shared moral impetus was to hold the Fascists accountable and not let them off the hook.

Environmental history is a powerful and illuminating perspective that sheds light on many facets of the Italian experience during the Fascist years. The story of Fascist "maladaptation" (Worster 2010) to the local ecology was just as much part of the story of Libyan occupation as the regime's wanton disregard for native interests and rights. But if the environment was the theater of action, it was the Fascists who wrote the murderous script, descending like "a destructive swarm of locusts", an analogy Graziani had mendaciously used in relation to the nomadic populations (123). As long as historians care about the profound moral and political questions thrown up by Fascist rule, the environment cannot and should not steal the show from the ruthless men who wreaked such havoc in it - and through it.

\section{Acknowledgements}

This article was researched and written in Covid19 times when travel restrictions were in place and archival visits restricted. I am grateful to Indiana University's Wells library for supplying me with what they could.

I would like to thank the two anonymous reviewers for their helpful comments and Mark Roseman for editorial suggestions.

\section{References}

[1] Ahmida, Ali Abdullatif. 2005. Forgotten Voices: Power and Agency in Colonial and Postcolonial Libya. New York: Routledge.

[2] Ahmida, Ali Abdullatif. 2021. Genocide in Libya. Shar, a Hidden Colonial History. New York: Routledge.

[3] Armiero, Marco. 2008. "Seeing Like a Protester: Nature, Power, and Environmental Struggles". Left History, 13(1): 59-76.

[4] Armiero, Marco and Wilko Graf von Hardenberg. 2013. "Green Rhetoric in Blackshirts: Italian Fascism and the Environment". Environment and History, 19(3): 283-311.

[5] Atkinson, David. 2000. "Nomadic Strategies and Colonial Governance: domination and resistance in Cyrenaica, 19231932". In The Entanglement of Power: Geographies of Domination/Resistance. Edited by Joanne Sharp et al., 93-121. London: Routledge

[6] Biasillo, Roberta and Claiton Marcio da Silva. 2019. "Cultivating Arid Soils in Libya and Brazil during World War Two: The Two-fold War between Colonial and Neo-colonial Experiences". Global Environments, 12(1): 154-181.

[7] Blackbourn, David. 2006. The Conquest of Nature. Water, Landscape and the Making of Modern Germany. New York: W. W. Norton \& Company.

[8] Blackmar, Elizabeth. 1994. "Contemplating the Force of Nature". Radical Historians Newsletter, 70: 1, 4, 16.

[9] Bonan, Giacomo. 2018. "Gli storici e l'Antropocene: narrazioni, periodizzazioni, dibattiti". Passato e presente XXXVI, 104: 129-143.

[10] Caprotti, Federico and Maria Kaïka. 2008. "Producing the ideal fascist landscape: nature, materiality and the cinematic representation of land reclamation in the Pontine Marshes". Social and Cultural Geography, 9(6): 613-634.

[11] Cavanagh, Edward, and Lorenzo Veracini (eds). 2017. The Routledge Handbook of the History of Settler Colonialism. New York: Routledge.

[12] Cavazza, Filippo. 1927. "Il problema della colonizzazione in Tripolitania". In Per le nostre colonie. Edited by Istituto agricolo coloniale italiano di Firenze, 73-100. Florence: Vallecchi.

[13] Cole, Tim. 2020. "Expanding (Environmental) Histories of the Holocaust". Journal of Genocide Research, 22(2): 273279.

[14] Cresti, Frederico. 2011. Non desiderare la terra d'altri. La colonizzazione italiana in Libia. Rome: Carocci.

[15] Cresti, Frederico. 1996. Oasi di Italianità. La Libia della colonizzazione agraria tra fascismo, guerra e indipendenza (1935-1956). Turin: Società editrice internazionale.

[16] Cresti, Federico. 2005. "The Early Years of the Agency for the Colonization of Cyrenaica (1932-1941)." In Italian Colonialism. Edited by Ben-Ghiat and Fuller, 73-82. New York: Palgrave Macmillan.

[17] Davis, Diana K. 2007. Resurrecting the Granary of Rome: Environmental History and French Colonial Expansion in North Africa. Athens: Ohio University Press.

[18] Del Boca, Angelo. 1986. Gli italiani in Libia. Vol. 1, Tripoli bel suol d'amore, 1860-1922. Rome: Laterza.

[19] Del Boca, Angelo. 1988. Gli italiani in Libia. Vol. 2, Dal fascismo a Gheddafi. Rome: Laterza.

[20] Ebner, Michael R. 2018. "Fascist Violence and the 'Ethnic Reconstruction' of Cyrenaica (Libya), 1922-1934". In Violence, Colonialism and Empire in the Modern World. Edited by Philip Dwyer and Amanda Nettelbeck. Cham: Palgrave Macmillan.

[21] Evans-Pritchard, E. E. 1949. The Sanusi of Cyrenaica. Oxford: Clarendon Press. 
[22] Folchi, Annibale. 2000. I contadini del Duce. Agro Pontino, 1932-1941. Rome: Pieraldo.

[23] Forth, Aidan and Jonas Kreienbaum. 2016. "A Shared Malady: Concentration Camps in the British, Spanish, American and German Empires". Journal of Modern European History, 14(2): 245-267.

[24] Ghosh, Amitav. 2017. The Great Derangement: Climate Change and the Unthinkable. Chicago: University of Chicago Press.

[25] Gott, Richard. 2007. "Latin America as a White Settler Society". Bulletin of Latin American Research, 26(2): 269289.

[26] Graziani, Rodolfo. 1932. Cirenaica pacificata. Milan: Mondadori.

[27] Herron, John. 2010. "Because Antelope Can't Talk: Natural Agency and Social Politics in American Environmental History". Historical Reflections, 1: 33-52.

[28] Holmboe, Knud. 1937. Desert Encounter: An Adventurous Journey through Italian Africa. New York: G. P. Putnam.

[29] Isenberg, Andrew C., Katherine G. Morrissey, and Louis S. Warren. 2019. "Imperial Deserts. Introduction". Global Environment, 12(1): 8-21.

[30] Iovino, Serenella. 2018. "Materia Agens, Materia Loquens. Ecocriticism and the Narrative Agency of Matter". Revista Canaria de Estudios Ingleses, 77: 11-25.

[31] Krautwurst, Udo. 2003. "What Is Settler Colonialism? An Anthropological Meditation on Frantz Fanon's 'Concerning Violence'". History and Anthropology, 14(1): 55-72.

[32] Labanca, Nicola. 2002. Oltremare. Storia dell'espansione colonial italiana. Bologna: Il Mulino.

[33] Lal, Vinay. 2005. "The Concentration Camp and Development: The Pasts and Future of Genocide". Patterns of Prejudice, 39(2): 220-243.

[34] Latour, Bruno. 1993. We Have Never Been Modern. Cambridge: Harvard University Press.

[35] Lessona, Alessandro. 1932. "La Cirenaica ad un anno dall'occupazione di Cufra". Gerarchia, 12(4): 265-270.

[36] Maugini, Armando. 1927. "La colonizzazione della Cirenaica". In Per le nostre colonie. Edited by Istituto agricolo coloniale italiano di Firenze, 133-155. Florence: Vallecchi.

[37] Munzi, Massimiliano. 2001. L'epica del ritorno. Archeologia e politica nella Tripolitania italiana. Rome: "L'Erma" di Bretschneider.

[38] Nash, Linda. 2005. "The Agency of Nature or the Nature of Agency?" Environmental History, 10(1): 67-69.

[39] Ottolenghi, Gustavo. 1997. Gli italiani e il colonialismo. I campi di detenzione italiani in Africa. Milan: SugarCo.

[40] Palloni, Giuseppe. 1945. I contratti agrari degli enti di colonizzazione in Libia. Florence: G.C. Sansoni.

[41] Pergher, Roberta. 2018. Mussolini's Nation-Empire: Sovereignty and Settlement in Italy's Borderlands, 19221943. Cambridge: Cambridge University Press.

[42] Pitzer, Andrea. 2017. One Long Night. A Global History of Concentration Camps. New York: Little, Brown and Company.

[43] Rava, Maurizio. 1928. "Demografia e colonizzazione. Esperienze e verità". L'Oltremare, 2(6): 213-216.

[44] Rochat, Giorgio. 1973. "La repressione della resistenza araba in Cirenaica nel 1930-31". Il movimento di liberazione in Italia, 25(110): 3-39.

[45] Rochat, Giorgio. 1981. "La repressione della resistenza in Cirenaica (1927-1931)". In Omar Al-Mukhtar e la Riconquista Fascista della Libia. Edited by Enzo Santarelli, Giorgio Rochat, Romain Rainero, Luigi Goglia. Milan: Marzorati.
[46] Ryan, Eileen. 2018. Religion as Resistance: Negotiating Authority in Italian Libya. New York: Oxford University Press.

[47] Salerno, Eric. 1979. Genocidio in Libia. Le atrocità nascoste dell'avventura coloniale italiana (1911-1931). Milan: SugarCo.

[48] Segrè, Claudio. 1974. Fourth Shore: The Italian Colonization of Libya. Chicago: University of Chicago Press.

[49] Stampacchia, Mauro. 2000. Ruralizzare l'Italia! Agricoltura e bonifiche tra Mussolini e Serpieri, 1928-1943. Milan: F. Angeli.

[50] Thomas, Julia Adeney. 2014. "History and Biology in the Anthropocene: Problems of Scale, Problems of Value". American Historical Review, 119(5): 1587-1607.

[51] Veracini, Lorenzo. 2010. Settler Colonialism: A Theoretical Overview. Hampshire, UK: Palgrave Macmillan.

[52] Wolfe, Patrick. 2006. "Settler Colonialism and the Elimination of the Native". Journal of Genocide Research, 8(4): 387-409.

[53] Worster, Donald. 2010. "Historians and Nature". The American Scholar, 1 March 2010. https://theamericanscholar.org/historians-and-nature/ (last access 01/25/2021).

[54] Worster, Donald. 1979. Dust Bowl: The Southern Plains in the 1930s. New York: Oxford University Press.

[55] Wright, John. 1969. Libya. New York: Praeger.

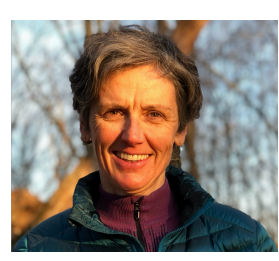

Roberta Pergher is Associate Professor of History at Indiana University.

She has published on Italian Fascism and its settlement policies including Mussolini's Nation-Empire: Sovereignty and Settlement in Italy's Borderlands, 19221943(Cambridge, 2017) and, with Marcus Payk, Beyond Versailles: Sovereignty, Legitimacy, and the Formation of New Polities after the Great War (Indiana, 2019). 